\title{
MulawarmanLawReview
}

\section{Burden of Proof Reversal in Criminal Acts of Money Laundering}

\author{
Muhammad Khusnul Fauzi Zainal' ${ }^{1}$, Syukri Akub², Andi Muhammad Sofyan ${ }^{3}$ \\ ${ }^{1}$ Magister Ilmu Hukum, Universitas Hasanuddin, Indonesia. \\ ${ }^{2}$ Fakultas Hukum, Universitas Hasanuddin, Indonesia. \\ ${ }^{3}$ Fakultas Hukum, Universitas Hasanuddin, Indonesia. \\ ${ }^{1}$ E-mail:m.khusnulfauzi@yahoo.com
}

\begin{abstract}
This study aims to analyze the burden of proof reversal system in handling cases of money laundering. This type of research is normative juridical legal research. The results of this study indicate that in the reversal system of the burden of proof of criminal acts of money laundering, each party has a burden of proof, the public prosecutor is burdened to prove that these assets are the property of the defendant and has a relationship with the original criminal act charged, while the defendant burdened to prove the origin of the assets claimed and if the defendant is unable to prove the origin of the assets, the assets can be strongly suspected to originate from criminal offenses. There are still obstacles in law enforcement both from the substance of the law (norms), legal structure (law enforcement agencies) and the culture of law (the culture of community law).
\end{abstract}

Keywords: Proof; Money laundering; Criminal act.

\section{ABSTRAK}

Penelitian ini bertujuan untuk menganalisis system pembalikan beban pembuktian dalam penanganan perkara tindak pidana pencucian uang. Tipe penelitian ini adalah penelitian hukum yang bersifat yuridis normatif. Hasil penelitian ini menunjukan bahwa dalam sistem pembalikan beban pembuktian tindak pidana pencucian uang pembuktian, masing-masing pihak memiliki beban pembuktian, pada penuntut umum dibebani untuk membuktikan bahwa harta kekayaan tersebut adalah milik terdakwa dan memiliki kaitan dengan tindak pidana asal yang didakwakan, sementara pada terdakwa dibebani untuk membuktikan asal muasal harta kekayaan yang didakwakan dan apabila terdakwa tidak mampu membuktikan asal muasal harta kekayaannya maka harta kekayaan tersebut dapat diduga keras berasal dari tindak pidana. Masih terdapat kendala dalam penegakan hukum baik dikaji dari substansi hukum (norma), struktur hukum (instansi penegakan hukum) dan kultur hukum (budaya hukum masyarakat).

Kata kunci: Pembuktian; Pencucian Uang; Tindak Pidana.

Citation: Fauzi Zainal, Muhammad Khusnul, Syukri Akub, and Andi Muhammad Sofyan. 2019. "Burden of Proof Reversal in Criminal Acts of Money Laundering". Mulawarman Law Review 4 (2), 98-104. https://doi.org/10.30872/mulrev.v4i2.60. 


\section{INTRODUCTION}

Law No. 8 Year 2010 considering Prevention and Eradication of The Criminal Acts of Money Laundering is not a new issue in legal positivism in Indonesia. Since 2002 as juridical reference of money laundering became legal in positivism in Indonesia

Money Laundering is an effort to conceal wealth in form of saving or assets that is obtained by unofficial method (result of criminal acts) becomes wealth which as if it is obtained by official resource. There are orientation differences in criminal acts where crime usually focus on defendants in criminal act of money laundering that fokus on wealth from criminal act result. Law No. 8 Year 2010 concerning the Prevention and Eradication of The Criminal Acts of Money Laundering is not a new issue in legal positivism in Indonesia.

Orientation is different from the handling of criminal acts of money laundering case makes case completion on ordinary criminal acts generally. It is because the proof regarding wealth source and its usage will be very difficult it is burdened to public prosecutors. It became based on proof system in criminal acts of money laundering uses burden of proof reversal system where the burden of proof is charged to the defendants.

Burden of proof reversal usage in criminal acts of money laundering because it is different with reversal proof in criminal acts of money laundering that is applied, where criminal acts of money laundering uses burden of proof which is limited and balanced, limited and balanced mean is even the Defendants cannot prove criminal acts of corruption that is committed but Public prosecutors must prove that it has correlation with criminal acts of money laundering. It is different with money laundering in law of criminal acts of money laundering does not explain regarding reversal proof by public prosecutors.

Based on the legal construction, this journal focus on two legal issues related with reversal burden system in handling of criminal acts of money laundring case as follows regarding the reversal proof of criminal acts of money laundering in case investigation on court and obstacles in the implementations of reversal burden proof in criminal acts of money laundring case.

\section{DISCUSSION}

Proof is based on word "proof" "Something that shows a truth on a phenomenon" then it is added prefix "pr" and suffix "oof" then proof means "act process, proof method to state truth of a phenomenon". ${ }^{1}$

Theoritically criminal procedural law studies known there are four legal concept of proof as follows as: First, legal concept of proof refers to legal positivism is on its starting point is on the existence of proofs limitatively are determined by law. Second, legal concept of proof based on on Judge's belief, where this concept emphasizes Judge's inner mind and absolute belief. In fact to achieve a decision they often used withc doctor or mystical power, etc. Third, legal concept of proof based on Judge's

\footnotetext{
${ }^{1}$ Andi Sofyan dan Abd Asis, Hukum Acara Pidana Suatu Pengantar, Kencana, Jakarta, 2014, hal. 230.
} 
belief in rational reason. Judge here prefers to be burdened to Judge's ability to decide a case with their inner mind and wisdom to decide a case. Fourth, legal concept of proof based on legal negativism, Judge only allows to decice a case if it fulfills proof limitatively which is determined by law and it is supported by Judge's belief toward related proofs existence.

Consequences of all four legal concepts are related with proof burden in the proof. It is examined from criminal law studies known there are 3 reversal burden concepts which are burden of proof on Public prosecutors. Logical consequence from this proof burden, that public prosecutors must prepare proofs accurately, if it is not will bo difficult to convice Judge considering Defendants mistake. ${ }^{2}$ Burden of proof on public prosecutors is proof burden system which is believed by by Criminal and Procedural Laws (KUHAP) are referred presumption of innocence in criminal court system in Indonesia where Criminal and Procedural Laws (KUHAP) regulate considering Defendants is not charged by burden of proof.

It is very clear explains considering burden of proof is burdened to Public prosecutors, Burden of Proof by the defendants in this context, Defendants has active role to state theirselves not as criminal suspect. Therefore, Defendants in front of court will prepare all proofs and if the cannot prove, Defendants will be stated as guilty by doing criminal act. Based on burden of proof in this type is named "Reversal Burden Proof" (Omkering Van Het Bewijslast or Shifting of Burden Of Proof / Onus of Proof) and balanced burden of proof where parties who have equal right and obligation in proof.

Law No. 8 in 2010 concerning the Prevention and Eradication of The Criminal Acts of Money Laundering regulates reversal burding in criminal acts of money laundering is regulated on Article 77 which states:

"For the purpose of the trial in a court of law, the Defendants must prove that the Assets do not constitute the proceeds of criminal acts".

Furthermore beside that article it is also explained in Article 78 paragraph (1) which stated:

1. During the court trial as referred to in Article 77, the Judges will order the defendant to prove that the Assets related with the case do not originate from or are not linked to criminal acts as referred to in Article 2 paragraph (1).

2. The defendant must prove that the Assets related with the case do not originate from and are not linked to criminal acts as referred to in Article 2 paragraph (1) by submitting sufficient proof.

From the regulation above is very clear that criminal acts of money laundering uses burden or proof reversal system where suspect/defendants must prove the origin of assets are not from criminal act as is regulated in Article 2 paragraph (1) and (2) on criminal acts of money laundering law.

\footnotetext{
${ }^{2}$ Lilik Mulyadi, Pembalikan Beban Pembuktian Tindak Pidana Korupsi, Alumni, Bandung, 2013 HIm 101
} 
It should clarifies the criminal acts of money laundering case uses reversal burden of proof also creates consequence that Defendantss cannot prove their assets are not linked to criminal acts, then the Prosecutor's accusation self is proved. ${ }^{3}$

Basically the usage of reersing burden of proof system in criminal acts of money laundering is tested on Constitutional Court by the Applicant Dr. M. Akil Mochtar, SH., $\mathrm{MH}$ with case number 77/PUU-XI/2014 where Applicant to hand over the proof authority to Public prosecutors because of several principles which is presumption of innocence, non self incrimination. But, it is denied by Council of Judge of Constitutional Court where in its decision clarifies.

"If a defendants have a good faith for legal certainly is not difficult for them to prove that the assets are not linked to criminal acts. On the contrary, Public prosecutors will be difficult to prove, in fact their criminal acts arome can be felt."

Author also has the same opinion with Council of Judges because the income flow or assets usage from criminal acts are very difficult to be investigated or found by other people. However, asset's owner is known the most its flow, reseource and asset's usage which is allowed then it is common that law uses burden of proof reversal system in proof of law enforcement and procedural system of handling of criminal acts of money laundering case.

\section{Proof Technical of Money Laundering}

Proof technical in case investigation in court of law is divided in accusation arrangement system by Public prosecutors, if it is arranged commulatively then money laundering accusation is arranged both after primary accusation (criminal acts origin), therefore concerning proof technical of Public prosecutors proves the first accusation uses reversal burden of system proof. Concsequence which is caused by accusation arrangement commulatively is if accusation toward criminal acts origin is not proven then necessarily the criminal acts of money laundering which is submitted in second accusation becomes unproven.

If criminal acts origin is not proven then the second accusation related with criminal acts of money laundering is also not proven, it is needed advanced investigation whether asset which is accused in criminal acts of money laundering accusation is earned officially or not and is it referred with criminal acts origin list as referred in Article 2 paragraph (1) and (2) on Criminal acts of money laundering law. It is needed to be known that accusation letter of criminal acts of money laundering arrangement must be explained clearly concerning criminal acts of money laundering which is the asset's origin principle, therefore if the accusation is arranged commulatively and clearly then the accusation is not proven, necessarily the accusation on criminal act of money laundering is not proven.

\footnotetext{
${ }^{3}$ Yudi Kristiana, Pemberantasan Tindak Pidana Pencucian Uang Perspektif Hukum Progresif, Thafamedia, Yogyakarta, 2015, hal. 263.
} 
Concerning accusation letter beside it is arranged commulatively where criminal acts origion is accused on the first accusation and criminal acts of money laundering is accused in the second accusation, Law of criminal acts of money laundering is also accomodated accusation that is arranged only one where it is arranged in Article 69 Law No. 8 Year 2010 which stated:

"In order to enable investigation, prosecution and trial in a court of law, regarding the money laundering crime, it is not mandatory to prove the predicate crime beforehand"

Grammatically not mandatory means not must have consequence which can be proved or not needed to be proved. If it is proved then proof can be processed to criminal acts origin, where it is spends a lot of time in proof process that is used single accusation. To prevent it, then the proof method is not needed because it is not efficient and the main idea of criminal acts of money laundering is not related with criminal acts origin but the asset's source whether it is legal/official or not. Public prosecutors just prove that there are causal correlations between criminal acts origin with the result of criminal acts. ${ }^{4}$

Referred to Syukri Akub, as Professor on Criminal Law of Hasanuddin University, that burden of proof reversal system in criminal acts of money laundering is absolute and limited, it means burden of proof must be charged to the Defendants and limited only to assets linked to criminal acts of money laundering. Therefore, related proof considering the fulfillment of offence elements on criminal acts of money laundering still must be proved by the Public prosecutors.

Interpretation of word "obligatory" in article 77 Law of Criminal Acts of Money Laundering consist imperative (forcing) meaning. It means if the Defendants cannot prove assets origin that becomes criminal acts of money laundering object then law consequence of the assets can be considered as assets linked to criminal acts origin which is accused to the Defendants.

It is not regulated the burden of Public prosecutors in proof of Criminal Acts of Money Laundering creates several asumptions considering procedural law is stiff cannot be interpreted more or less. It causes perception toward burden of proof by Public prosecutors in criminal acts of money laundering. Does Public prosecutors not need to prove their accusation proof in trial?

Article 77 and Article 78 of Law of Criminal Acts of Money Laundering does not erase the authority/burden of Public Prosecutor in this criminal acts of oney laundering based on thinking construction when Public Prosecutors arrange the accusations based on sufficient proof and prosecutors belief is formed that assets which accused are linked to criminal acts. Although, Judge commands Defendant to prove that the accusation is not related with criminal act origin that is accused by Public Prosecutor.

\footnotetext{
${ }^{4}$ Tubagus Irman, Money Laundering Hukum Pembuktian Tindak Pidana Pencucian Uang dalam Penetapan Tersangka, Gramedia Pustaka Utama, Jakarta, 2017, Hal. 216.
} 
Beside, Public Prosecutor also have proof in form of financial profile of the Defendants until reach the conclusion that the assets are earned by unofficial method. ${ }^{5}$

Burden of proof reversal on criminal acts of money laundering which is pure but it is limited that causes consequence the existence of burden toward Public Prosecutor to prove delicts of criminal acts of another money laundering beside considering the defendants assets origin. Thinking construction above also as basic of Public Prosecutors also have obligation to prove their accusation on case investigation in court of law

\section{Burden of Proof Reversal System on The Council of Criminal Acts of Money Laundering}

Obstacles in law enforcement in Lawrence M. Friedman theory is divided into 3 types, Legal Structure (structure of legal system) which is the whole legal institutions, Substances (substance of legal system) which is rule and Legal Culture (legal culture) which are opinion, belief, habit, mind set and behavior on law enforcers or people generally. ${ }^{6}$

Related with problematics of law enforces are observed from law substance aspect ${ }^{7}$ is still considered there are issues especially related to procedural law because legal act in procedural law system must be done with responsibility and referred to law's provisions then there will be no raping in defendants rights in trial. ${ }^{8}$

Issues on the law substance convers: First, the unclear regulation considering the burden of proof reversal usage in criminal acts of money laundering. Proof system in handling of case is vital because based on proof a public prosecutor, Defendant can convince Judge related the occurrence / not a criminal act phenomenon. Whereas in criminal acts of money laundering still use multi-interpretation in proof implementation. Therefore, referred to UUTPU pure burden of proof which is charged to the Defendants. However, burden of reversal proof absolutely is a new issue in criminal and procedural laws then in proof procedural is still confusing for law enforcers.

Beside, there are no technical guideline of proof of burden reversal system purely then recently proof still charges Public Prosecutors to proof their accusation even in certain limits.

Related problematics of burden of proof reversal implementation in handling of criminal acts of money laundering case, on law enforcer departments still do not have eveness consideration considering technical burden of proof reversal. The oddness of

\footnotetext{
${ }^{5}$ Yudi Kristiana, Op.cit, hal. 266.

${ }^{6}$ Amir Ilyas dan Jupri, Justice Collaborator Strategi Mengungkap Tindak Pidana Korupsi, Genta Publishing, Yogyakarta 2018, hal. 87.

7 Azhar, I. (2018). Manajemen Hakim (Studi Perbandingan Indonesia dengan Turki). Mulawarman Law Review, 3(1), 48-65. Retrieved from https://ejournal.fh.unmul.ac.id/index.php/mulrev/article/view/33

${ }^{8}$ Amir Ilyas dan Apriyanto Nusa, Praperadilan Pasca Putusan Mahkamah Konstitusi, Genta Publishing, Yogyakarta, 2017, hal. 6.
} 
consideration is caused by the unclear of procedural law considering criminal acts of money laundering then law enforces will be difficult to run the procedural law.

\section{CONCLUSION}

Burden of proof reversal system on criminal acts of money laundering is charged to the defendants and does not clarify considering burden of proof by Public Prosecutor. Whereas on its implementation on Public Prosecutors or defendants have each portion in proving a criminal act of money laundering. Obstacle in burden of proof reversal system on trial investigation in court of law on criminal acts of money laundering is law substance obstacle and law structre. It is ideal to be implemented revision on Law No. 8 Year 2010 considering Prevention and Eradication of The Criminal Acts of Money Laundering to emphasize proof system which used is pure or balanced. Law norm refinement also must be supported by socialization toward law enforcers considering the importance of prevention and eradication of criminal acts of money laundering to return assets to the country, breaking the criminal chain and to restore loss of criminal acts victims.

\section{BIBLIOGRAPHY}

Amir Ilyas dan Apriyanto Nusa. (2017). Praperadilan Pasca Putusan Mahkamah Konstitusi. Yogyakarta: Genta Publishing.

Amir Ilyas dan Jupri. (2018). Justice Collaborator Strategi Mengungkap Tindak Pidana Korupsi. Yogyakarta: Genta Publishing.

Andi Sofyan dan Abd Asis. (2014). Hukum Acara Pidana Suatu Pengantar. Jakarta: Kencana.

Azhar, I. (2018). Manajemen Hakim (Studi Perbandingan Indonesia dengan Turki). Mulawarman Law Review, 3(1), 48-65. Retrieved from https://ejournal.fh.unmul.ac.id/index.php/mulrev/article/view/33.

Soerjono Soekanto. (1986). Kriminologi Suatu Pengantar. Jakarta: Ghalia Indonesia.

Soerjono Soekanto dan Sri Mamudji. (2006). Penelitian Hukum Normatif. Jakarta: Raja Frafindo Persada.

Lawrence M. Friedman. (2001). Hukum Amerika: Sebuah Pengantar (American Law: An Introduction). Jakarta: PT. Tatanusa.

Tubagus Irman. (2017). Money Laundering Hukum Pembuktian Tindak Pidana Pencucian Uang dalam Penetapan Tersangka. Jakarta: Gramedia Pustaka Utama.

Undang-Undang No 10 Tahun 2010 Tentang Pencegahan dan Pemberantasan Tindak Pidana Pencucian Uang.

Yudi Kristiana. (2015). Pemberantasan Tindak Pidana Pencucian Uang Perspektif Hukum Progresif. Yogyakarta: Thafamedia. 